\title{
Genetic and serological typing of European infectious haematopoietic necrosis virus (IHNV) isolates
}

\author{
Tove Johansson ${ }^{1,6, *}$, Katja Einer-Jensen ${ }^{1}$, William Batts ${ }^{2}$, Peter Ahrens ${ }^{3}$, \\ Carina Björkblom $^{4}$, Gael Kurath ${ }^{2}$, Harry Björklund ${ }^{5}$, Niels Lorenzen ${ }^{1}$ \\ ${ }^{1}$ National Veterinary Institute, Technical University of Denmark, Hangøvej 2, 8200 Århus N, Denmark \\ ${ }^{2}$ Western Fisheries Research Center, US Geological Survey, 6505 NE 65th Street, Seattle, Washington 98115, USA \\ ${ }^{3}$ Statens Serum Institut, Artillerivej 5, 2300 Copenhagen, Denmark \\ ${ }^{4}$ Laboratory of Aquatic Pathobiology, Åbo Akademi University, Artillerigatan 6 A 2, 20520 Åbo, Finland \\ ${ }^{5}$ Orion Pharma, PO Box 425, 20101 Åbo, Finland \\ ${ }^{6}$ Present address: Laboratory of Aquatic Pathobiology, Department of Biology, Åbo Akademi University, \\ Artillerigatan 6 A 2, 20520 Åbo, Finland
}

\begin{abstract}
Infectious haematopoietic necrosis virus (IHNV) causes the lethal disease infectious haematopoietic necrosis (IHN) in juvenile salmon and trout. The nucleocapsid (N) protein gene and partial glycoprotein (G) gene (nucleotides 457 to 1061) of the European isolates IT-217A, FR-32/87, DE-DF 13/98 11621, DE-DF 4/99-8/99, AU-9695338 and RU-FR1 were sequenced and compared with IHNV isolates from the North American genogroups U, M and L. In phylogenetic studies the N gene of the Italian, French, German and Austrian isolates clustered in the M genogroup, though in a different subgroup than the isolates from the USA. Analyses of the partial G gene of these European isolates clustered them in the M genogroup close to the root while the Russian isolate clustered in the U genogroup. The European isolates together with US-WRAC and US-Col-80 were also tested in an enzyme-linked immunosorbent assay (ELISA) using monoclonal antibodies (MAbs) against the $\mathrm{N}$ protein. MAbs 136-1 and 136-3 reacted equally at all concentrations with the isolates tested, indicating that these antibodies identify a common epitope. MAb 34D3 separated the M and L genogroup isolates from the U genogroup isolate. MAb 1DW14D divided the European isolates into 2 groups. MAb 1DW14D reacted more strongly with DE-DF 13/98 11621 and RU-FR1 than with IT-217A, FR32/87, DE-DF 4/99-8/99 and AU-9695338. In the phylogenetic studies, the Italian, French, German and Austrian isolates clustered in the M genogroup, whereas in the serological studies using MAbs, the European M genogroup isolates could not be placed in the same specific group. These results indicate that genotypic and serotypic classification do not correlate.
\end{abstract}

KEY WORDS: Infectious haematopoietic necrosis virus · IHNV · Europe $\cdot$ Nucleocapsid protein · Glycoprotein · Phylogeny · Enzyme-linked immunosorbent assay $\cdot$ ELISA

\section{INTRODUCTION}

Infectious haematopoietic necrosis virus (IHNV) is the causative agent of the highly lethal disease infectious haematopoietic necrosis (IHN) in juvenile rainbow trout Oncorhynchus mykiss, Pacific salmon
Oncorhynchus spp. and Atlantic salmon Salmo salar (Bootland \& Leong 1999). IHNV has also been isolated from eel (Bergmann et al. 2003). IHNV belonging to the family Rhabdoviridae has a single-stranded RNA genome of negative polarity consisting of 6 genes coding for 5 virion proteins: nucleocapsid protein $(\mathrm{N})$, 
phosphoprotein $(\mathrm{P})$, matrix protein $(\mathrm{M})$, glycoprotein (G) and the polymerase (L); and one non-virion (NV) protein (Fauquet et al. 2005).

IHNV was first observed in cultured sockeye salmon on the west coast of North America (Bootland \& Leong 1999). Currently IHNV in North America is found from Alaska to northern California along the Pacific coast and inland to Idaho (Kurath et al. 2003). In Asia IHNV has been isolated from fry and fingerlings of Pacific salmon Oncorhynchus spp. and rainbow trout in Japan (Nishizawa et al. 2006) and from juvenile rainbow trout and masu salmon Oncorhynchus masou in Korea (Kim et al. 2007). In 1987 IHNV was isolated from rainbow trout yolk sac fry in Italy (Bovo et al. 1987) and from rainbow trout fry and fingerlings in France (Laurencin 1987). Since then isolation of IHNV in Europe has been reported from Austria (Kolodziejek et al. 2008), Germany (Fichtner et al. 2000, Enzmann et al. 2005), Belgium (World Organisation for Animal Health 2007) and Switzerland (Knuesel et al. 2003). The first outbreak of IHN in rainbow trout fry in Russia was in 2000 in Moscow province (Schelkunov et al. 2001).

Phylogenetic analyses based on the most variable region within the G gene of IHNV isolates from the west coast of USA and Canada have identified the existence of 3 major genogroups, L (lower), M (middle) and U (upper) (Kurath et al. 2003). The genogroups occur in different geographic areas: $U$ in Alaska, Washington coast and Columbia River Basin, USA, and British Columbia, Canada; $\mathrm{M}$ in Idaho and Columbia River Basin; and L in California and Oregon coast. The $\mathrm{M}$ genogroup is divided into 6 subgroups (A to E) and L into two (1 and 2) whereas $U$ is not divided into subgroups (Kurath et al. 2003, Troyer \& Kurath 2003). An earlier phylogenetic analysis of the partial G gene sequences (303 nucleotides [nt]) of IHNV isolates from North America included one index case isolate from France and one from Italy (Kurath et al. 2003). In later studies the complete G and NV gene sequences were determined for 9 German isolates and the French index isolate (Enzmann et al. 2005) and for a $615 \mathrm{bp}$ region of the $\mathrm{G}$ gene of Austrian isolates (Kolodziejek et al. 2008). Phylogenetic analysis in all these reports showed that the European isolates fell within the M genogroup. Electrophoretic typing, monoclonal antibody (MAb) analysis, T1 ribonuclease fingerprinting and gene sequencing of IHNV isolates have shown that identical or almost identical isolates are found within a certain geographic location independent of host species (Hsu et al. 1986, Ristow \& Arnzen de Avila 1991, Nichol et al. 1995, Oshima et al. 1995, Kurath et al. 2003). Among the European isolates, a panel of French isolates have previously been studied using MAbs against the $\mathrm{N}$ protein in indirect immunofluo- rescence (Danton et al. 1994) and the IT-217A and FR-32/87 isolates have been characterised using MAbs against the G protein (Arkush et al. 1989).

In the present study the complete $\mathrm{N}$ gene and a $605 \mathrm{nt}$ partial G gene sequence of 6 representative IHNV isolates from Italy, France, Germany, Austria and Russia were determined and compared with isolates from the 3 major genogroups from the west coast of USA and Canada. Our results confirm previous work and expand our understanding of European IHNV to include isolates from additional countries, with phylogenetic trees constructed based on analysis of a different viral gene. Further European isolates were also serologically characterised using MAbs against the $\mathrm{N}$ protein in enzyme-linked immunosorbent assays (ELISA).

\section{MATERIALS AND METHODS}

Cells and virus. IHNV isolates used for sequencing the full-length $\mathrm{N}$ gene and part of the G gene (corresponding to nt 457 to 1061, numbering from the open reading frame; GenBank accession no. L40882) were AU-9695338, DE-DF 13/98 11621, DE-DF 4/99-8/99, FR-32/87, IT-217A and RU-FR-1 (Table 1). RU-FR1 is the same isolate referred to as Ryb00TF in Rudakova et al. (2007). Additionally the N gene of the USA isolates described in Table 1 (except for US-RB-1) was sequenced. The European isolates were also used in an ELISA together with isolates US-WRAC and USCol-80 where reactivity of MAbs against the N protein was tested. Epithelioma papulosum cyprini (EPC) (Fijan et al. 1983) and bluegill fry (BF-2) (Wolf et al. 1966) cells were grown in Eagle's minimum essential medium (MEM) supplemented with 10\% fetal calf serum, $2 \mathrm{mM}$ L-glutamine and $100 \mathrm{IU} \mathrm{ml}^{-1}$ penicillin. EPC cells were infected with IHNV and BF-2 cells were infected with viral haemorrhagic septicaemia virus (VHSV) at a multiplicity of infection (MOI) of 0.1 and kept at $15^{\circ} \mathrm{C}$ until full $(100 \%)$ cytopathic effect developed. IHNV particles were concentrated from $3 \mathrm{ml}$ tissue culture supernatant by ultracentrifugation at $86000 \times g$ for $1 \mathrm{~h}$ at $4^{\circ} \mathrm{C}$. Genomic RNA of IHNV was extracted using the RNeasy mini kit (Qiagen). The RNA was eluted with $35 \mu \mathrm{l}$ RNase-free $\mathrm{H}_{2} \mathrm{O}$, and $5 \mu \mathrm{l}$ (approximately $1 \mu \mathrm{g}$ RNA) was used for RT-PCR.

RT-PCR and sequencing. Primers for RT-PCR were designed based on previously published sequences of IHNV (GenBank accession nos. X73872, X89213 and NC_001652). For encompassing the entire $N$ gene a primer pair with the forward primer 5'-CGA GAC AGA ACA AGC AGA A-3' and the reverse primer 5'CAT TGT TGT GGT TTG AGT TGA-3' (nt 107 to 125 
Table 1. Infectious haematopoietic necrosis virus (IHNV) isolates used. G: glycoprotein gene; N: nucleocapsid protein gene. ps: sequenced in the present study

\begin{tabular}{|c|c|c|c|c|c|}
\hline Isolate & $\begin{array}{c}\text { ps or GenBank } \\
\text { acc. no. }\end{array}$ & Host species & $\begin{array}{c}\text { Year of } \\
\text { isolation }\end{array}$ & $\begin{array}{l}\text { Country } \\
\text { or region }\end{array}$ & Source \\
\hline FR-32/87 & ps & Oncorhynchus mykiss & 1987 & France & Laurencin (1987) \\
\hline IT-217A & ps & O. mykiss & 1987 & Italy & Bovo et al. (1987) \\
\hline AU-9695338 & ps & O. mykiss & 1996 & Austria & Dr. N. J. Okson ${ }^{a}$ \\
\hline DE-DF 13/98 11621 & ps & Anguilla anguilla & 1998 & Germany & Bergmann et al. (2003) \\
\hline DE-DF 4/99-8/99 & ps & O. mykiss & 1999 & Germany & Fichtner et al. (2000) \\
\hline RU-FR1 & ps & O. mykiss & 2000 & Russia & Schelkunov et al. (2001) \\
\hline US-RB-1 & G: U50401, N: U50402 & O. mykiss & 1975 & OR, USA & Kurath et al. (1997) \\
\hline US-RB-76 & G: L40880, N: AY442516 & Steelhead & 1976 & OR, USA & Nichol et al. (1995) \\
\hline US-LWS-87 & L40879 & O. tshawytscha & 1987 & WA, USA & Nichol et al. (1995) \\
\hline US-BLK-94 & DQ164100 & O. nerka & 1994 & WA, USA & Garver et al. (2006) \\
\hline US-WRAC & L40882 & O. mykiss & 1982 & ID, USA & Nichol et al. (1995) \\
\hline US-193-110 & G: L40871, N: AY442507 & O. mykiss & 1984 & ID, USA & Nichol et al. (1995) \\
\hline US-HO-7 & G: L40876, N: AY442512 & O. mykiss & 1984 & ID, USA & Nichol et al. (1995) \\
\hline US-SRCV & G: L40881, N: AY442517 & O. tsawytscha & 1966 & CA, USA & Nichol et al. (1995) \\
\hline US-Col-80 & G: L40873, N: AY442509 & O. tsawytscha & 1980 & CA, USA & Nichol et al. (1995) \\
\hline US-Col-85 & G: L40873, N: AY442510 & Steelhead & 1985 & CA, USA & Nichol et al. (1995) \\
\hline KR-PRT & G: AY673684, N: AY673683 & O. mykiss & 1991 & Korea & Kim et al. (2007) \\
\hline
\end{tabular}

and 1468 to 1448 of the WRAC strain of IHNV NC_001652, respectively) were used. The primers for amplifying the G gene were 5'-CAG AGA CCC ACC AAA ACA-3' (forward) and 5'-AAG TGA AGA TTG AGG TCC TTT A-3' (reverse) (nt 2969 to 3001 and 4556 to 4523 of the WRAC strain of IHNV NC_001652, respectively). The Titan one-tube RT-PCR system (Roche Diagnostics) was used for RT-PCR. The reverse transcription reaction was run at $50^{\circ} \mathrm{C}$ for 30 min prior to a 2 min denaturation at $94^{\circ} \mathrm{C}$. The PCR program with 36 cycles was $94^{\circ} \mathrm{C}$ for $30 \mathrm{~s}, 54^{\circ} \mathrm{C}$ for $30 \mathrm{~s}$ and $68^{\circ} \mathrm{C}$ for $1 \mathrm{~min}$. The RT-PCR products were excised from a $2 \%$ agarose gel and purified using the QIAquick gel extraction kit (Qiagen). Both strands of the PCR products were sequenced using an ABI 377 automatic sequencer (Applied Biosystems). The same primers as for RT-PCR plus internal primers were used for sequencing the $\mathrm{N}$ gene. For sequencing the $\mathrm{G}$ gene, forward primer 5'-AAG AAG CAG GGG CGT A-3' and reverse 5'-TGT CCT TGG ATA CCT CGT CC-3' (nt 3387 to 3402 and 4103 to 4084 of the WRAC strain of IHNV NC_001652, respectively) were used. For isolate DE-DF 4/99-8/99, primer 5'-AGC AGG GGC GTA TGA CAC-3' (nt 3391 to 3408) was used for sequencing the sense strand of the $\mathrm{G}$ gene. The sequence data has been deposited in GenBank under accession numbers FJ265710 to FJ265715 (N gene) and FJ265716 to FJ265721 (G gene).

Sequence analysis and phylogenetic trees. The sequences were aligned using ClustalX (Thompson et al. 1997) and GeneDoc (Nicholas et al. 1997). ModelTest (Posada \& Crandall 1998) and PAUP version 4.0b 10 (Swofford 2003) was used for the phylogenetic analysis. Phylogenetic analysis was conducted using the neighbour-joining program with 1000 bootstrapped replicates and branches with bootstrap values $<70 \%$ collapsed. The Sacramento River Chinook virus (SRCV) from California (L genogroup) was used as the outgroup.

ELISA. ELISA was performed according to the procedure described by Olesen \& Jørgensen (1991) with minor modifications. Briefly, 96-well microtitre plates were coated with protein A purified polyclonal rabbit anti-IHNV $\left(0.14 \mu \mathrm{g} \mathrm{well}{ }^{-1}\right)$ and incubated at $4^{\circ} \mathrm{C}$ overnight. The plates were washed with $0.1 \mathrm{M}$ PBS$0.05 \%$ Tween-20 then incubated with IHNV (equal amount of virus particles bound to coating antibody in each well; stock solution approximately $10^{8} \mathrm{TCID}_{50}$ $\mathrm{ml}^{-1}$ ) for $1 \mathrm{~h}$ at room temperature (RT). After the second wash, MAbs against the N protein where European isolates have been used for MAb production, 136-1, 136-2, 2F4/F3, 34D, or the US-MAb 1DW14D considered to identify a common epitope were added at a 3-fold increasing dilution (from the dilution giving the highest optical density [OD] value at absorbance at $492 \mathrm{~nm}\left[A_{492}\right]$ to the end point) and the plates were incubated for $1 \mathrm{~h}$ at RT (Table 2 gives detailed information and references for the MAbs). After another wash, horseradish-peroxidase (HRP)-conjugated rabbit anti-mouse immunoglobulins (P0260; DAKO) was added and the plates were incubated for $1 \mathrm{~h}$ at RT. After a final wash, the substrate ortho-phenylene diamine was added and $A_{492}$ was measured. Fifty $\mu \mathrm{l} \mathrm{VHSV} \mathrm{(Voldbjerg)} \mathrm{(approxi-}$ mately $2 \times 10^{8} \mathrm{TCID}_{50} \mathrm{ml}^{-1}$ ) and cell growth medium were used as controls. 
Table 2. Monoclonal antibodies (MAbs) against the nucleocapsid (N) protein used in ELISA. MAb stock solutions were hybridoma cell culture supernatants with approximate mouse Ig concentration of 5 to $15 \mu \mathrm{g} \mathrm{ml}^{-1}$

\begin{tabular}{|lcll|}
\hline Antibody & $\begin{array}{c}\text { Isolate(s) for } \\
\text { MAb production }\end{array}$ & MAb dilution & Source \\
\hline 136-1 & FR-32/87 & $400^{-1}$ to $874800^{-1}$ & Dr. N. J. Olesen, Denmark \\
136-3 & FR-32/87 & $400^{-1}$ to $874800^{-1}$ & Fregeneda-Grandes et al. (2009) \\
2F4/F3 & US-OSV, IT-217A & $400^{-1}$ to $874800^{-1}$ & Veselý et al. (2004) \\
34D3 & FR-32/87 & $100^{-1}$ to $218700^{-1}$ & Dr. M. Dauber, Germany; Bio-X Diagnostics Sprl, Belgium \\
1DW14D & US-DW2 & $400^{-1}$ to $874800^{-1}$ & Ristow \& Arnzen (1989), Chen et al. (1991), \\
& & & Ristow \& Arnzen de Avila (1991), Danton et al. (1994) \\
\hline
\end{tabular}

\section{RESULTS}

\section{Sequence comparison of $\mathbf{N}$ protein}

The $\mathrm{N}$ gene of the European and American IHNV isolates is $1173 \mathrm{bp}$ in length and encodes a protein of 391 amino acids. AU-9695338, DE-DF 13/98 11621, DE-DF 4/99-8/99, FR-32/87 and IT-217A were 98 to $99 \%$ identical at the nucleotide level and RU-FR1 was 95 to $96 \%$ identical to these European isolates and $98 \%$ identical to the American isolates from the U genogroup. The European M genogroup isolates were 97 to $98 \%$ identical to the other M genogroup isolates and 95 to $96 \%$ identical to the L genogroup isolates. At the amino-acid level, AU-9695338, DE-DF 13/98 11621, DE-DF 4/99-8/99, FR-32/87 and IT-217A were 98 to $100 \%$ identical among themselves and 94 to $96 \%$ identical with RU-FR1. European M genogroup isolates were 96 to $98 \%$ identical with US-M genogroup isolates whereas RU-FR1 was $96 \%$ identical with these isolates at the amino-acid level. AU-9695338, DE-DF 13/98 11621, DE-DF 4/99-8/99, FR-32/87, IT-217A and RU-FR1 were all 94 to $95 \%$ identical with US-L genogroup isolates.

The European IHNV isolates, when compared to the French 07-71 (GenBank accession no. AJ233396) and German Fi13 (GenBank accession no. X73873) isolates of VHSV, showed an identity of around $50 \%$.

\section{Sequence comparison of $G$ protein (nt 457 to 1061)}

The 605 nt partial G gene sequence of AU-9695338, DE-DF 13/98 11621, DE-DF 4/99-8/99, FR-32/87 and IT-217A were 97 to $99 \%$ identical. The nucleotide diversity between these European isolates and the Russian isolate was 2 to $3 \%$ and between the Russian isolate and the American U genogroup isolates was $1 \%$. Differences between the European isolates and American isolates were between 1 and $5 \%$. The American isolate Col-85 differed most from the European isolates. The European IHNV, when compared to the
French 07-71 (GenBank accession no. AJ233396) and German Fi13 (GenBank accession no. 73873) isolates of VHSV at the nucleotide level, showed an identity of 52 to $53 \%$.

\section{Phylogenetic studies of $\mathbf{N}$ gene and partial $\mathrm{G}$ gene}

The $\mathrm{N}$ gene (Fig. 1A) and partial G gene (Fig. 1B,C) of the European isolates were used in phylogenetic studies together with isolates from the west coast of USA and Canada. The phylogenetic trees of the $\mathrm{N}$ gene (Fig. 1A) and G gene (nt 457 to 1061; Fig. 1B) consist of the same virus isolates for comparison. In a neighbour-joining distance tree, where branches with bootstrap values $<70 \%$ were collapsed, the isolates from Austria, Germany, France and Italy clustered in the $M$ genogroup together with isolates from Idaho and the Columbia River Basin whereas the Russian isolate was in the U genogroup with isolates from Alaska and British Columbia. A phylogenetic analysis of the 303 nt mid-G region of the G genes was also conducted to assess relationships in a larger data set with more North American isolate sequences (Fig. 1C). In the mid-G tree, the Austrian, German, French and Italian isolates were again in the $M$ genogroup, but did not cluster into any of the known subgroups (A to E). In the $\mathrm{N}$ gene tree, the $\mathrm{M}$ genogroup was divided into 2 subgroups, the European isolates and the American isolates, which therefore represent 2 distinct virus lineages. In the European lineage, IT-217A is in a separate branch from the other European isolates, AU9695338, DE-DF 4/99-8/99, DE-DF 13/98 11621 and FR-32/87. This monophyletic origin of the European IHNV isolates is not evident in either of the partial G gene trees. In all trees the branch lengths in the $U$ genogroup are shorter than in the M genogroup, indicating less nucleotide diversity. The branch points for the 3 major genogroups L, M and U in all trees as well as for the 2 distinct lineages in the $\mathrm{M}$ genogroup in the $\mathrm{N}$ gene tree were well supported by the bootstrap values. 


\section{ELISA}

MAbs 136-1 and 136-3 reacted equally at all concentrations with all isolates included in the present study, indicating that these antibodies identify a common epitope (data not shown). The dilution factors for MAb 136-1 and MAb 136-3 at an $\mathrm{OD}_{492}$ value of 0.5 were 1:3600 and 1:32400 respectively. MAb 34D3 reacted equally with AU-9695338, DE-DF 4/99-8/99, DE-DF 13/98 11621, IT-217A, FR-32/87 and the US isolates, whereas it did not react at all with RU-FR1 (Fig. 2A). The reaction of MAb 2F4/F3 was strongest with RU-FR1 and the US isolates and equal among the European isolates (Fig. 2B). MAb 1DW14D reacted well with the US isolates, the RU-FR1 isolate and the German isolate 13/98 11621. AU-9695338, DE-DF 4/99-8/99, FR-32/87 and IT-217A reacted with MAb 1DW14D at higher concentrations of the MAb (Fig. 2C). The MAbs did not react with the negative control VHSV. All the MAbs were specific for the viral $\mathrm{N}$ protein and no cross-reaction with the G protein or EPC cells was observed.

\section{DISCUSSION}

The nucleotide sequence of the $\mathrm{N}$ gene (full length) and partial G gene (nt 457 to 1061) of IHNV isolates from Austria, Germany, France, Italy and Russia was determined by sequencing RT-PCR products. This is the first study to analyse the $\mathrm{N}$ gene of several European IHNV isolates and the first genetic characterisation using complete gene sequences of IHNV isolates from Austria, Italy and Russia. The nucleotide diversity among the European isolates (excluding RU-FR1) was 1 to $2 \%$ for the $\mathrm{N}$ gene and 2 to $3 \%$ for the partial G gene. The nucleotide diversity within the U genogroup (excluding KR-PRT) was $2 \%$ for the $\mathrm{N}$ gene and $1 \%$ for
A

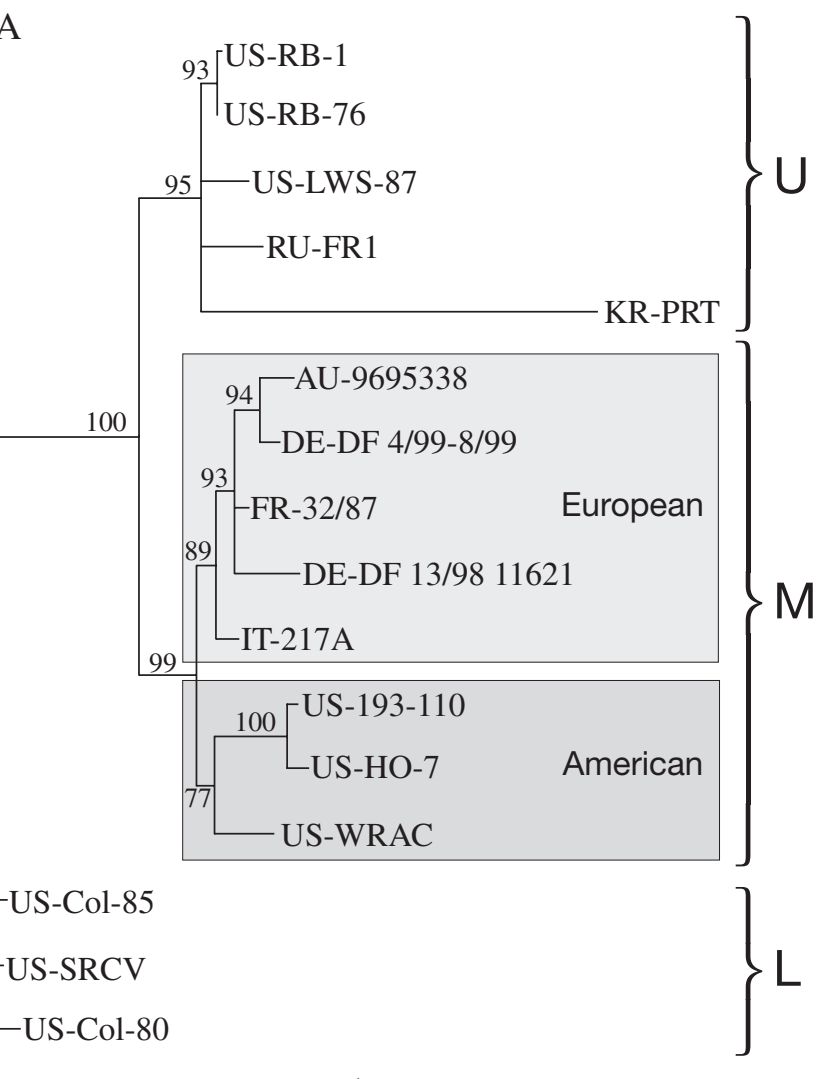

B

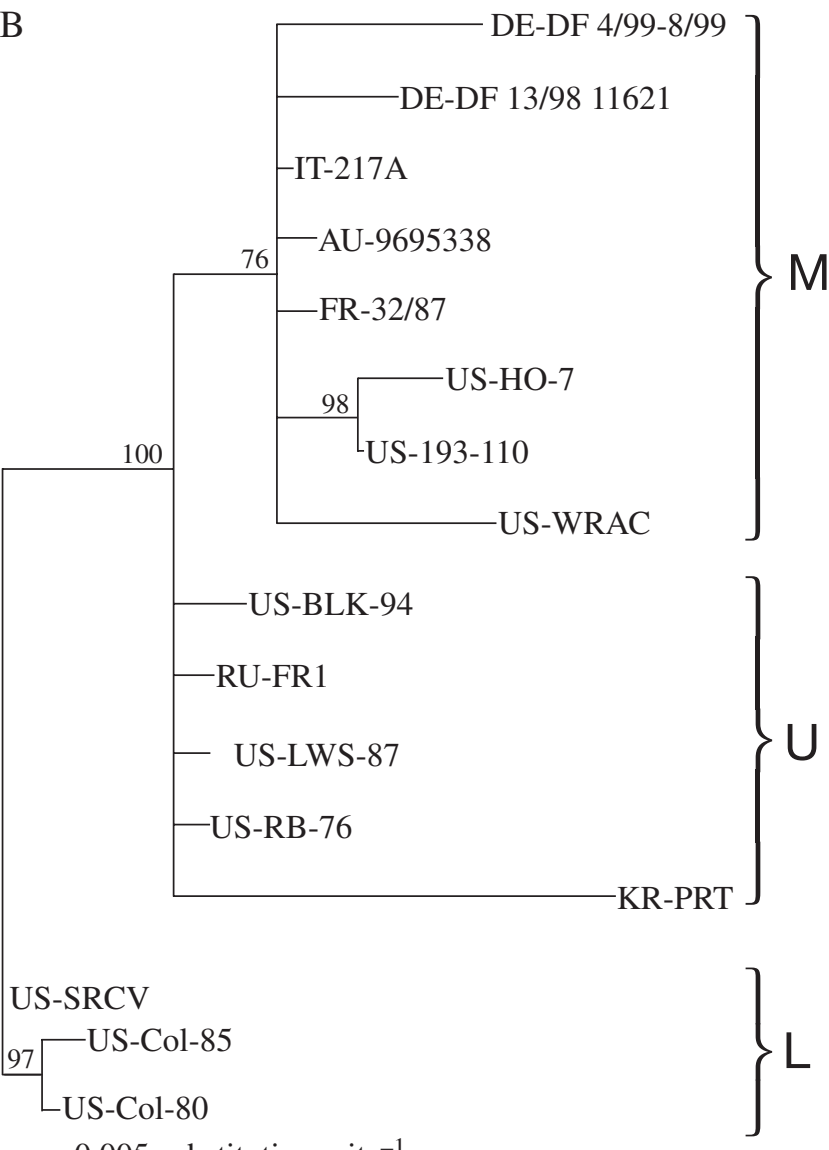

Fig. 1. Phylogenetic trees of (A) the nucleocapsid protein $(N)$ gene, $(B)$ the glycoprotein $(G)$ gene (nt 457 to 1061$)$ and $\left(C_{;}\right.$next page) mid-G region of the G gene (nt 686 to 988) of infectious haematopoietic necrosis virus (IHNV) isolates. All trees were created using the neighbour-joining distance program. The bootstrap values are percentage of 1000 different trees. U, M and L refer to the major genogroups. In (B), US-RB-1 was replaced with US-BLK-94 due to $100 \%$ identity with isolate US-RB-76. In (C), IT217A and AU-9695338 were considered as one due to $100 \%$ identity. In addition to the isolates included in (A) and (B), isolates from Garver et al. (2003) and Troyer \& Kurath (2003) were included in (C). See Table 1 for GenBank accession numbers 


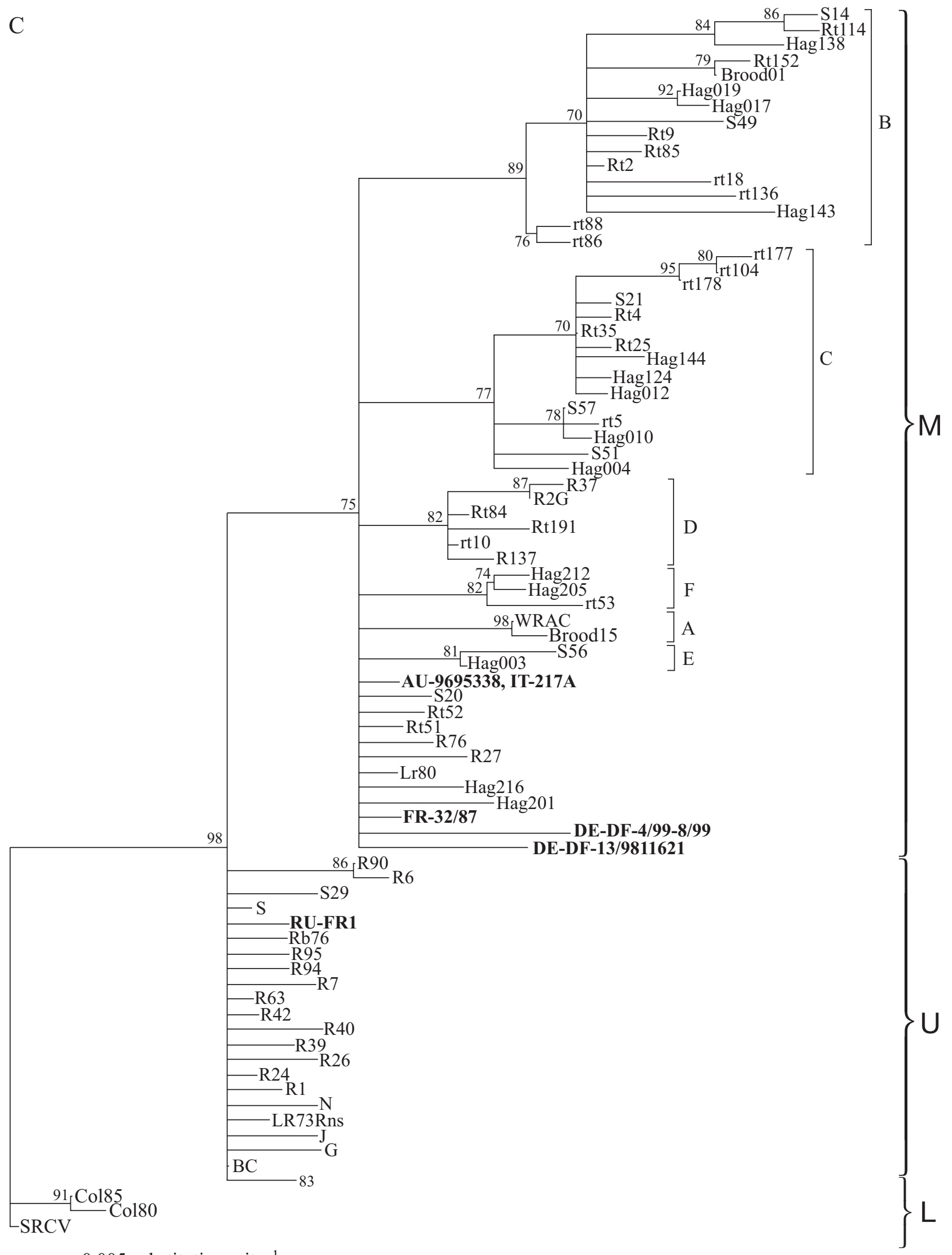

Fig. 1 (continued) 

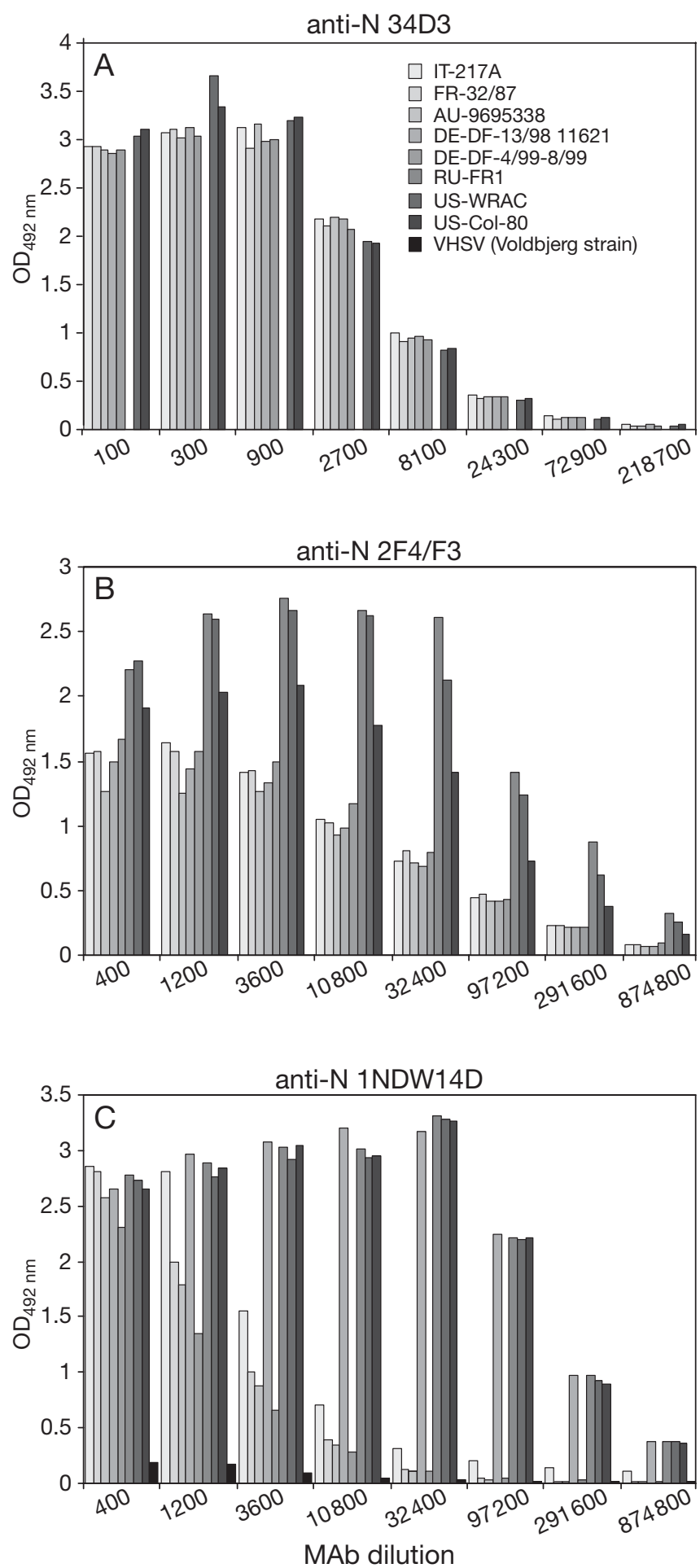

Fig. 2. Comparison of the reaction of the monoclonal antibodies (MAbs) (A) 34D3, (B) 2F4/F3 and (C) 1NDW14D against the nucleocapsid $(\mathrm{N})$ protein of the European infectious haematopoietic necrosis virus (IHNV) isolates IT-217A, FR-32/87, AU-9695338, DE-DF 13/98 11621 and DE-DF 4/998/99, the Russian isolate RU-FR1 and the North American isolates WRAC and Col-80. The Voldbjerg strain of the viral haemorrhagic septicaemia virus (VHSV) was used as a control. $\mathrm{OD}_{492 \mathrm{~nm}}$ : optical density at $492 \mathrm{~nm}$ the partial G gene (nt 457 to 1061). The nucleotide diversity of IHNV isolates has been shown to vary depending on their region of origin. The nucleotide diversity among French isolates has been shown to be $<5 \%$ (Cozien \& Thiéry 2003) and among Japanese isolates $5 \%$ at a maximum (Nishizawa et al. 2006). The lowest regional diversity is found among isolates from Alaska (2 to $3 \%)$, British Columbia (1.6\%) and coastal Washington (Emmenegger et al. 2000, Emmenegger \& Kurath 2002, Kurath et al. 2003). The highest diversity is among isolates from the Idaho region with a maximum nucleotide divergence in the mid-G region of 7.6\% (Troyer et al. 2000).

In all phylogenetic studies reported here (full-length N gene, partial G gene [nt 457 to 1067] or mid-G region [nt 686 to 988]), AU-9695338, DE-DF 13/98 11621, DEDF 4/99-8/99, FR-32/87 and IT-217A clustered in the M genogroup whereas RU-F1 fell in the U genogroup. In the $\mathrm{N}$ gene tree the European isolates formed a distinct monophyletic virus lineage within the $M$ genogroup supported by the high bootstrap value. In our mid-G tree, where M genogroup isolates from Idaho (Troyer \& Kurath 2003) and isolates from Columbia River basin (Garver et al. 2003) were included, the European isolates did not cluster in any specific subgroup. Thus, in phylogenetic studies to date, European isolates of IHNV have been shown to cluster in the M genogroup with isolates from Idaho and Columbia River basin (the present study, Cozien \& Thiéry 2003, Enzmann et al. 2005, Kolodziejek et al. 2008) and when full-length gene sequences are analysed, the European isolates form a distinct virus lineage ( $\mathrm{N}$ gene in the present study, G and NV genes in Enzmann et al. 2005). The finding that the Italian, Austrian and French isolates appear monophyletic with the German isolates suggests that there is a monophyletic origin for all IHNVs in Europe. The placement of the single Russian isolate into the U genogroup is consistent with typing results of Russian IHNV isolates based on the 303 nt mid-G region (Rudakova et al. 2007). The original source of RUFR1 is not known; however, it has been shown that RUFR1 appears to be divergent from the IHNV isolates from sockeye salmon in Kamchatka, which are very similar to IHNV isolates from northwestern North America (Rudakova et al. 2007). The branch lengths in the U genogroup were shorter than the branch lengths in the $\mathrm{M}$ genogroup (except for the Korean isolate), as has been shown previously with North American and Russian isolates (Garver et al. 2003, Kurath et al. 2003, Rudakova et al. 2007).

In the present study, AU-9695338, DE-DF 4/99-8/99, DE-DF 13/98 11621, FR-32/87, IT-217A and RU-FR1, together with US isolates WRAC and Col-80, were also tested by ELISA using 5 MAbs against the $\mathrm{N}$ protein. FR-32/87 and IT-217A have previously been analysed 
using MAbs against the glycoprotein and results showed that they clearly differ from isolates from California (Arkush et al. 1989). In addition antibodies developed against isolates from Oregon (RB-76) and Idaho (193-110) neutralised these European isolates (Arkush et al. 1989).

The reaction with MAbs 136-1 and 136-3 showed no differences between the European and US isolates, indicating that these antibodies identify a common epitope. RU-FR1, a U genogroup isolate, was the only isolate not reacting with MAb 34D3. Reaction with the MAb 2F4/F3 divided the isolates into 2 groups, with RU-FR1 and the US isolates in one group, reacting more strongly with the MAb, and the Austrian, German, French and Italian isolates in the other group. The MAb 1NDW14D, thought to identify a common epitope on the N protein (Ristow \& Arnzen 1989), did not react as strongly with the AU-9695338, DE-DF 4/99-8/99, FR-32/87 and IT-217A isolates as it did with DE-DF 13/98 11621 and the US isolates. According to previous studies, MAb 1NDW14D reacts with the Cterminal end of the $\mathrm{N}$ protein (Chen et al. 1991). Among the isolates used in the ELISA, differences at the amino-acid level at the C-terminal end of the $\mathrm{N}$ protein were found at positions 380 and 381. Amino acid 380 in AU-9695338, DE-DF 4/99-8/99 and FR$32 / 87$ was tyrosine, whereas in the US isolates RU-FR1 and DE-DF 13/98 11621 and also IT-217A it was aspartic acid. Amino acid 381 in IT-217A was proline and in all other isolates it was serine. The weaker reaction with AU-9695338, DE-DF 4/99-8/99, FR-32/87 and IT$217 \mathrm{~A}$ could be due to substitutions of these amino acids. French isolates, including isolate 32/87, of IHNV have been typed previously with MAb 1NDW14D using indirect immunofluorescence (Danton et al. 1994). Not including isolate $32 / 87$, only 5 of the 27 isolates tested reacted with MAb 1NDW14D (Danton et al. 1994).

It has been shown that IHNV isolates found within a localised geographic area typically have identical or nearly identical nucleotide sequences, independent of host species (Hsu et al. 1986, Ristow \& Arnzen de Avila 1991, Nichol et al. 1995, Oshima et al. 1995, Kurath et al. 2003). In phylogenetic studies the European IHNV isolates are divided into genogroups and subgenogroups corresponding to the geographic region they were isolated from, whereas in serological studies one exception is found with the isolate DE-DF 13/98 11621 from eel (the other European isolates being isolated from rainbow trout), which reacted differently with MAb 1NDW14D. Considerable variation among the epitopes of the nucleoprotein of French IHNV isolates from rainbow trout has previously been shown (Danton et al. 1994). The different reaction of DE-DF 13/98 11621 can therefore be due to either the consid- erable variation among the epitopes in general among IHNV isolates, or to DE-DF 13/98 11621 having been isolated from a different species. In conclusion, although serological typing of virus isolates with MAbs does not fully correlate with the genotyping in the present study, ELISA remains a valid diagnostic tool for the rapid grouping of IHNV isolates. By using a targeted approach with a focus on generation of genotype-specific antibodies, it is likely that a robust and versatile typing system could be developed.

Acknowledgements. We thank L. Troels for excellent technical assistance. This research was financially supported by the European Union research project EU-FAIR CT98-4064 and the Academy of Finland. Mention of trade names does not imply US Government endorsement. Dr. M. Dauber, Friedrich Loeffler Institute, Insel Reims, Germany, is thanked for supplying monoclonal antibody 34D3 to IHNV.

\section{LITERATURE CITED}

Arkush KD, Bovo G, de Kinkelin P, Winton JR, Wingfield WH, Hedrick RP (1989) Biochemical and antigenic properties of the first isolates of infectious hematopoietic necrosis virus from salmonid fish in Europe. J Aquat Anim Health 1: 148-153

Bergmann SM, Fichtner D, Skall HF, Schlotfeldt HJ, Olesen NJ (2003) Age- and weight-dependent susceptibility of rainbow trout Oncorhynchus mykiss to isolates of infectious haematopoietic necrosis virus (IHNV) of varying virulence. Dis Aquat Org 55:205-210

Bootland LM, Leong JC (1999) Infectious hematopoietic necrosis virus. In: Woo PTK, Bruno DW (eds) Fish diseases and disorders, Vol 3. CAB International, Wallingford, p 57-112

Bovo G, Giorgetti G, Jørgensen PEV, Olesen NJ (1987) Infectious haematopoietic necrosis: first detection in Italy. Bull Eur Assoc Fish Pathol 7:124

Chen L, Ristow S, Leong JC (1991) Epitope mapping and characterization of the infectious hematopoietic necrosis virus nucleoprotein. In: Proc 2nd Int Symp Viruses of Lower Vertebrates, 29-31 Jul 1991. Oregon State University Press, Corvallis, OR, p 65-72

Cozien J, Thiéry R (2003) Genetic and virulence comparison of French isolates of infectious haematopoietic necrosis virus. In: Abstracts Book, 11th Int Conf Eur Assoc Fish Pathol, Malta, 21-26 Sep 2003. EAFP, Malta, oral presentation O-2

Danton M, Ristow SS, Hattenberger-Baudouy AM, de Kinkelin P (1994) Typing of French isolates of infectious haematopoietic necrosis virus (IHNV) with monoclonal antibodies using indirect immunofluorescence. Dis Aquat Org 18: $223-226$

Emmenegger EJ, Kurath G (2002) Genetic characterisation of infectious hematopoietic necrosis virus of coastal salmonid stocks in Washington state. J Aquat Anim Health 14: $25-34$

Emmenegger EJ, Meyers TR, Burton TO, Kurath G (2000) Genetic diversity and epidemiology of infectious hematopoietic necrosis virus in Alaska. Dis Aquat Org 40: 163-176

> Enzmann PJ, Kurath G, Fichtner D, Bergmann SM (2005) Infectious hematopoietic necrosis virus: monophyletic ori- 
gin of European isolates from North American Genogroup M. Dis Aquat Org 66:187-195

Fauquet CM, Mayo MA, Maniloff J, Desselberger U, Ball L (2005) Virus taxonomy: VIIIth report of the International Committee on Taxonomy of Viruses. Elsevier Academic Press, London

Fichtner D, Bergmann S, Enzmann PJ, Granzow H, Schütze H, Mock D, Schäfer JW (2000) Isolation and characterisation of a variant strain of infectious haematopoietic necrosis (IHN) virus. Bull Eur Assoc Fish Pathol 20:135-142

Fijan N, Sulimanovič D, Bearzotti M, Muzinič D and others (1983) Some properties of the epithelioma papulosum cyprinid (EPC) cell line from carp Cyprinus carpio. Ann Inst Pasteur Virol 134:207-220

Fregeneda-Grandes JM, Skall HF, Olesen NJ (2009) Antibody response of rainbow trout with single or double infections involving viral haemorrhagic septicaemia virus and infectious haematopoietic necrosis virus. Dis Aquat Org 83:23-29

- Garver KA, Troyer RM, Kurath G (2003) Two distinct phylogenetic genogroups of infectious hematopoietic necrosis virus overlap within the Columbia River basin. Dis Aquat Org 55:187-203

Garver KA, Batts WN, Kurath G (2006) Virulence comparisons of infectious hematopoietic necrosis virus $U$ and $M$ genogroups in sockeye salmon and rainbow trout. J Aquat Anim Health 18:232-243

Hsu Y, Engelking HM, Leong JC (1986) Occurrence of different types of infectious hematopoietic necrosis virus in fish. Appl Environ Microbiol 52:1353-1361

Kim WS, Oh MJ, Nishizawa T, Park JW, Kurath G, Yoshimizu M (2007) Genotyping of Korean isolates of infectious hematopoietic necrosis virus (IHNV) based on the glycoprotein gene. Arch Virol 152:2119-2124

Knuesel R, Segner H, Wahli T (2003) A survey of viral diseases in farmed and feral salmonids in Switzerland. J Fish Dis 26:167-182

Kolodziejek J, Schachner O, Dürrwald R, Latif M, Nowotny N (2008) "Mid-G" region sequences of the glycoprotein gene of Austrian infectious hematopoietic necrosis virus isolates form two lineages within European isolates and are distinct from American and Asian lineages. J Clin Microbiol 46:22-30

Kurath G, Higman KH, Björklund H (1997) Distribution and variation of NV genes in fish rhabdoviruses. J Gen Virol 78:113-117

Kurath G, Garver KA, Troyer RM, Emmenegger EJ, EinerJensen K, Anderson ED (2003) Phylogeography of infectious haematopoietic necrosis virus in North America. J Gen Virol 84:803-814

Laurencin FB (1987) IHN in France. Bull Eur Assoc Fish Pathol 7:104

Nichol ST, Rowe JE, Winton JR (1995) Molecular epizootiology and evolution of the glycoprotein and non-virion protein genes of infectious hematopoietic necrosis virus, a fish rhabdovirus. Virus Res 38:159-173

Nicholas KB, Nicholas HB Jr, Deerfield DW II (1997) GeneDoc: analysis and visualization of genetic variation. EMBnet News 4(2):1-4, available at www.embnet.org

Editorial responsibility: Mark Crane,

Geelong, Victoria, Australia
Nishizawa T, Kinoshita S, Kim WS, Higashi S, Yoshimizu M (2006) Nucleotide diversity of Japanese isolates of infectious hematopoietic necrosis virus (IHNV) based on the glycoprotein gene. Dis Aquat Org 71:267-272

> Olesen NJ, Jørgensen PEV (1991) Rapid detection of viral haemorrhagic septicaemia virus in fish by ELISA. J Appl Ichthyol 7:183-186

- Oshima KH, Arakawa CK, Higman KH, Landolt ML, Nichol ST, Winton JR (1995) The genetic diversity and epizootiology of infectious hematopoietic necrosis virus. Virus Res 35:123-141

Posada D, Crandall KA (1998) Modeltest: testing the model of DNA substitution. Bioinformatics 14:817-818

- Ristow SS, Arnzen JM (1989) Development of monoclonal antibodies that recognize a type- 2 specific and a common epitope on the nucleoprotein of infectious hematopoietic necrosis virus. J Aquat Anim Health 1:119-125

$>$ Ristow SS, Arnzen de Avila J (1991) Monoclonal antibodies to the glycoprotein and nucleoprotein of infectious hematopietic necrosis virus (IHNV) reveal differences among isolates of the virus by fluorescence, neutralization and electrophoresis. Dis Aquat Org 11:105-115

Rudakova SL, Kurath G, Bochkova EV (2007) Occurrence and genetic typing of infectious hematopoietic necrosis virus in Kamchatka, Russia. Dis Aquat Org 75:1-11

Schelkunov IS, Schelkunova TI, Kupinskaya OA, Didenko LV, Bykovsky AF, Olesen NJ (2001) Infectious haematopoietic necrosis (IHN): the first confirmed finding in Russia. In: Abstracts Book, 10th Int Conf Eur Assoc Fish Pathol, Dublin 9-14 Sep 2001. EAFP, Dublin, poster no. $\mathrm{P}-044$

Swofford DL (2003) PAUP*. Phylogenetic analysis using parsimony ( ${ }^{*}$ and other methods), Version 4. Sinauer Associates, Sunderland, MA

Thompson JD, Gibson TJ, Plewniak F, Jeanmougin F, Higgins DG (1997) The ClustalX windows interface: flexible strategies for multiple sequence alignment aided by quality analysis tools. Nucleic Acids Res 25:4876-4882

> Troyer RM, Kurath G (2003) Molecular epidemiology of infectious hematopoietic necrosis virus reveals complex virus traffic and evolution within southern Idaho aquaculture. Dis Aquat Org 55:175-185

> Troyer RM, LaPatra SE, Kurath G (2000) Genetic analyses reveal unusually high diversity of infectious haematopoietic necrosis virus in rainbow trout aquaculture. J Gen Virol 81:2823-2832

Veselý T, Nevoránková Z, Hulová J, Reschová S, Pokorová D (2004) Monoclonal antibodies to the nucleoprotein and glycoprotein of the virus of infectious haematopoietic necrosis of salmonids (IHNV) and their use in immunoperoxidase test. Bull Eur Assoc Fish Pathol 24: $218-230$

Wolf K, Gravell M, Malsberger R (1966) Lymphocystis virus: isolation and propagation in centrarchid fish cell lines. Science 151:1004-1005

World Organisation for Animal Health (OIE) (2007) OIE world animal health situation. OIE, Paris, www.collabcen. net/idaad/diseasecountries. aspx? $\mathrm{t}=\mathrm{a} \& \mathrm{id}=93 \& \mathrm{did}=55$ (accessed 24 Oct 2007

Submitted: October 8, 2008; Accepted: June 29, 2009 Proofs received from author(s): October 9, 2009 